Revista Brasileira de Farmacognosia Brazilian Journal of Pharmacognosy 22(4): 768-774, Jul./Aug. 2012

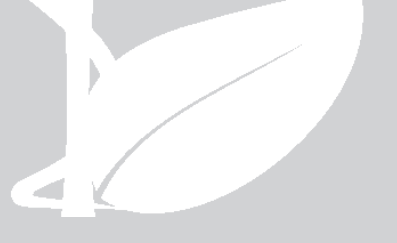

Article

Received 29 Nov 2011

Accepted 12 Jan 2012

Available online 21 Jun 2012

Keywords:

ecology

physiology

seaweed

environmental impacts

pharmacognosy

ISSN 0102-695X

http://dx.doi.org/10.1590/S0102695X2012005000085

\section{Evaluation of impacts of climate change and local stressors on the biotechnological potential of marine macroalgae - a brief theoretical discussion of likely scenarios}

\author{
Paulo A. Horta, ${ }^{*}$, Talita Vieira-Pinto, ${ }^{1}$ Cintia D. L. Martins, ${ }^{1}$ \\ Marina N. Sissini, ${ }^{1}$ Fernanda Ramlov, ${ }^{1}$ Cintia Lhullier, ${ }^{1}$ \\ Fernando Scherner, ${ }^{3}$ Paola F. Sanches, ${ }^{1}$ Julyana N. Farias, ${ }^{3}$ \\ Eduardo Bastos, ${ }^{1}$ Janayna L. Bouzon, ${ }^{1}$ Pamela Munoz, ${ }^{1}$ Eduardo \\ Valduga, ${ }^{1}$ Noele P. Arantes, ${ }^{1}$ Manuela B. Batista, ${ }^{1}$ Pablo Riul, ${ }^{2}$ \\ Rafael S. Almeida, ${ }^{1}$ Eduardo Paes, ${ }^{5}$ Alessandra Fonseca, ${ }^{1}$ Eloir \\ P. Schenkel, ${ }^{1}$ Leonardo Rorig, ${ }^{1}$ Zenilda Bouzon, ${ }^{1}$ José Bonomi \\ Barufi, ${ }^{1}$ Pio Colepicolo, ${ }^{6}$ Nair Yokoya, ${ }^{4}$ Margareth S. Copertino, ${ }^{7}$ \\ Eurico C. de Oliveira ${ }^{1}$
}

\author{
${ }^{1}$ Programa de Pós-graduação em Biologia Vegetal, Departamento de Botânica, Centro \\ de Ciências Biológicas, Universidade Federal de Santa Catarina, Brazil, \\ ${ }^{2}$ Departamento de Engenharia e Meio Ambiente, CCAE, Universidade Federal da \\ Paraiba, Rio Tinto, Brazil, \\ ${ }^{3}$ Programa de Pós-graduação em Botânica, Laboratório de Ficologia, Universidade \\ Federal Rural de Pernambuco, Brazil, \\ ${ }^{4}$ Programa de Pós-graduação em Biodiversidade Vegetal e Meio Ambiente, Instituto de \\ Botânica, Brazil, \\ ${ }^{5}$ Instituto Sócio Ambiental e Recursos Hidricos, Universidade Federal Rural do \\ Amazonas, Brazil, \\ ${ }^{6}$ Departamento de Bioquímica, Instituto de Química, Universidade de São Paulo, \\ Brazil, \\ ${ }^{7}$ Laboratório de Ecologia Vegetal Costeira, Departamento de Oceanografia, Universidade \\ Federal do Rio Grande, Brazil.
}

\begin{abstract}
Climate change can be associated with variations in the frequency and intensity of extreme temperatures and precipitation events on the local and regional scales. Along coastal areas, flooding associated with increased occupation has seriously impacted products and services generated by marine life, in particular the biotechnological potential that macroalgae hold. Therefore, this paper analyzes the available information on the taxonomy, ecology and physiology of macroalgae and discusses the impacts of climate change and local stress on the biotechnological potential of Brazilian macroalgae. Based on data compiled from a series of floristic and ecological works, we note the disappearance in some Brazilian regions of major groups of biotechnological interest. In some cases, the introduction of exotic species has been documented, as well as expansion of the distribution range of economically important species. We also verify an increase in the similarities between the Brazilian phycogeographic provinces, although they still remain different. It is possible that these changes have resulted from the warming of South Atlantic water, as observed for its surface in southeastern Brazilian, mainly during the winter. However, unplanned urbanization of coastal areas can also produce similar biodiversity losses, which requires efforts to generate long-term temporal data on the composition, community structure and physiology of macroalgae.
\end{abstract}

Introduction

While the causes of climate change remain controversial (see Zagoni, 2010), there seems to be little question that some environmental changes are related, either directly or indirectly, to human activities. In Brazil and worldwide, extreme events related to variations in temperature and precipitation 
have received media attention due to the loss of human life and economic resources, yet the impact on products and services represented by the biodiversity of coastal areas, in particular marine macroalgae, has received very little discussion.

The data presented by the IPCC (2007) highlight a warming process in the South Atlantic that is likely to intensify according to projections made for the coming years, reaching values $4.5^{\circ} \mathrm{C}$ above current sea surface temperatures. Along with rising temperatures, scenarios were hypothesized that predict an increased intensity and frequency of storms (Emanuel, 2007). Taken together, these factors are reasonably predictive of changes we might expect to take place in the composition and abundance of macroalgal communities. Even taken singly, such climate variations call for actions that might mitigate their overall effect. At the same time, the effects of climate change on macroalgae should be considered in the context of increasing urbanization of coastal areas.

Urbanization is a major selective force peculiar to the Anthropocene (Steffen et al., 2011), a period of planetary history that begins after the Industrial Revolution in the late nineteenth century. Besides changing the landscape, runoff in urban areas results in an increasing concentration and production of effluents, especially those of domestic origin, resulting in fertilization of adjacent environments with large amounts of dissolved organic and inorganic nutrients. Problems related to organic pollution are especially important in developing countries, where sewage treatment does not exist or is inadequate and/ or inefficient (Marques et al., 2004). In addition, urban areas represent a source of toxic pollutants derived, for example, from the combustion of petroleum. Together with the sources of disturbances already described, this increases the impact on the biology of organisms that depend of coastal environments.

Therefore, the dual effects of climate change coupled with increasing occupation of coastal areas have significant potential to induce the loss of diversity and, with it, the biotechnological potential of macrobenthic communities, especially macroalgae, in coastal environments. These organisms have traditionally been harvested or cultivated as a food source, such as agar or carrageenan, or for the extraction of secondary metabolites used in the pharmaceutical industry (Marinho-Soriano et al., 2011). In this context, representatives of the genera Laurencia and Dictyota (Lhullier et al., 2010; Domingos et al., 2011; Garrido et al., 2011; Machado et al., 2011; Moura et al., 2011) are target organisms for studies on many different levels of pharmaceutical investigation. Based on a review of the available literature, this paper presents an analysis of the current distribution, together with several aspects of macroalgae diversity, highlighting evidence that identifies how environmental factors related to climate change and the presence of local anthropogenic stressors can affect the ecology and physiology of macroalgae and, consequently, their biotechnological potential.

\section{Materials and Methods}

Utilizing the CAPES Periodicals Portal, this paper reviewed information related to floristic, taxonomic, ecological and physiological aspects of Brazilian macroalgae. We focused on an analysis of environments with different degrees of urbanization, further seeking a historical perspective by showing changes in macroalgae composition over the past year. Based on these results, we discuss likely scenarios related to the diversity of seaweeds in the context of proposed IPCC (2007) models and related works that present predictions of future environmental conditions.

The phycogeographic analyses were based on data derived from the reviews of Horta et al. (2001) and Fujii et al. (2008). The similarity analysis utilized the Bray-Curtis index, spatialized according a Multidimensional Scaling approach (MDS). The significance of the differences between the values of similarity between the different provinces was evaluated by using analysis of similarities (ANOSIM). For these tests, we used the PRIMER 6.0 program. To map populations of Laminaria abyssalis, available data in the dissertation of Quége (1988) were used, while data on sea surface temperatures in that region were obtained from the National Oceanic and Atmospheric Administration database (NOAA), a United States agency focused on the condition of the oceans and the atmosphere.

\section{Results and Discussion}

As highlighted by Horta et al. (2001), Brazilian flora is represented by two biogeographic provinces, denominated by these authors as tropical and warm temperate. Comparing the similarities between the provinces studied by them with the values obtained from the analysis of Fujji et al. (2008), we found an increase in the similarities between these provinces, although significant differences remain between them (Figure 1). This reduction of similarity values was related to the observed variation in species composition between these regions, as indicated by the advancement of taxonomic assessment, in most cases, and the most recent listing of a number of species with restricted distribution in the south, southeast and northeast coastal areas. On the one hand, variations in composition represent an expansion of the biotechnological potential of macroalgae because an expansion of the distribution 
range widens the sampling area, allowing new research groups to investigate taxa of interest for many different purposes, including industrial or pharmaceutical. On the other hand, the introduction of exotic species has been documented in some cases (Horta \& Oliveira, 2000; Cassano et al., 2008), as well as an expanded distribution range of economically important species, such as the genus Hypnea (Faveri et al., 2010). These changes may be a result of the warming tendency of the Atlantic observed in the last decades (Marengo \& Camargo, 2007) or be due to the interaction of this factor with other factors related to anthropogenic activities. Independent of the causes of the distribution changes, the occupation of new environments by these species can result in further selective pressures, imposing new limits on the potential phenotypic plasticity of these taxa. In this way, a new set of environmental conditions may result in favorable conditions for the synthesis of new substances or their synthesis at different concentrations, reinforcing the importance of continued monitoring of the biology of these organisms.

Moreover, seawater warming could produce negative effects on the biology of these organisms. Using as an example the results of the experiment with Laurencia dendroidea reported by Sudatti et al. (2011), it was observed that the reduction in the production of elatol has important ecological consequences, added to the physiological effect on the biotechnological potential of the species. Higher temperatures lead to increased susceptibility of the herbivore population, due to the reduction of the production of elatol and to eventual increases in grazing pressure related to the herbivore metabolic rates (Dillon et al., 2010). Therefore, overall, the increase in temperature could result in a reduction in the biomass of the population, which in turn would result in a reduction of substances of biotechnological interest, such as elatol. It is therefore recommended that further studies be conducted to determine the nature of the interaction with herbivores since this cascading effect, if demonstrated, would have a devastating effect on the genus Laurencia, a group of red algae with a high biotechnological potential.

Also, considering the restricted distribution of populations with a strong dependence on lower temperatures, the heating process can represent their exclusion or even extinction. This is especially important to economically important groups represented by Pyropia (as Porphyra in traditional references), and especially by Laminaria abyssalis (YoneshigueValentin, 1990; Rodrigues et al., 2000), which is distributed in coastal waters of southeastern Brazil at depths between 40-120 $\mathrm{m}$ with temperatures ranging from $15-20{ }^{\circ} \mathrm{C}$ in a region where only $0.5 \%$ of the light incident on the surface is observed near the bottom. However, we can hypothesize that any change that leads to increased sea surface warming in this region (Figure 2) could result in severe negative impacts or even in the extinction of this species. Since this is a species endemic to the Brazilian coast and has high biotechnological importance (Romanos, 2002a, b), this possibility deserves our special attention.

The increase and frequency of storms associated with climate change (Emanuel, 2007) cause related phenomena such as reduced water clarity, increased sedimentation, a sharp reductions in salinity or even increased hydrodynamic force, which exacerbate the stress on the biology of seaweeds. The increase of temperature and the salinity reduction, for example, can be related to a substantial reduction in the synthesis of elatol, resulting in limited physiological performance imposed by the variation of different environmental factors directly and indirectly related to climatic events (Sudatti et al., 2011). Increased rainfall commonly results in increased erosion and continental runoff, and
A)

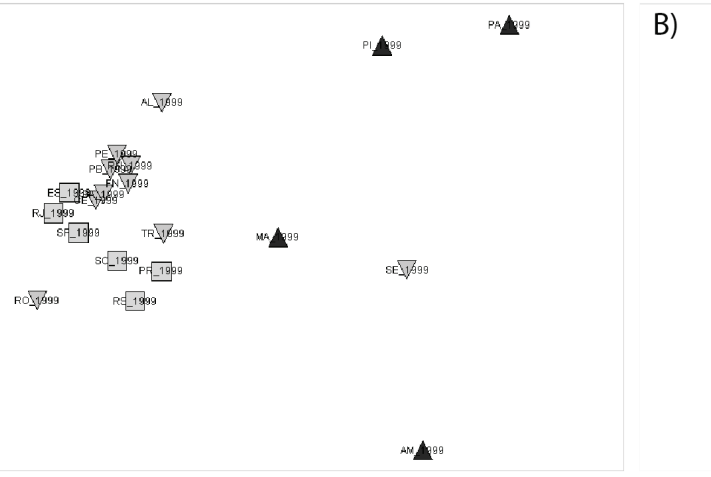

B)

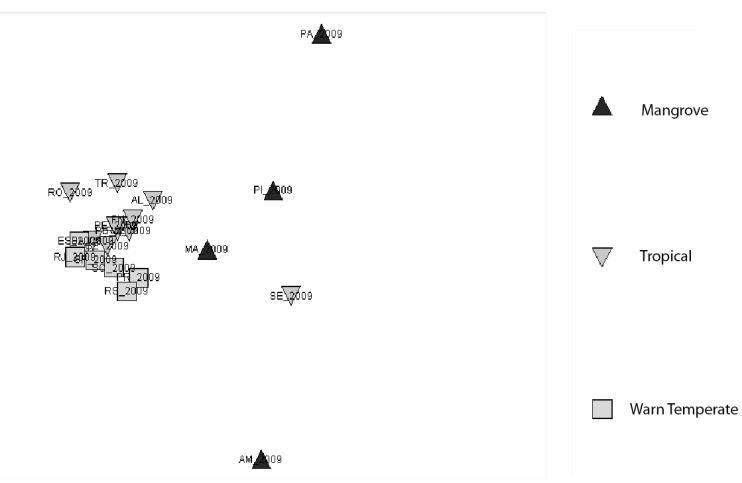

Figure 1. MDS analysis of Brazilian seaweed flora (followed by ANOSIN significance evaluation) of Tropical, Warm Temperate provinces, considering the States as sampling areas. a) MDS based on Horta et al. (2001) and b) MDS based on Fujii et al. (2008). ANOSIN reinforces the reduction of differences observed in the MDS between tropical and warm temperate provinces based on data available in 2000 (Horta et al., 2001) and eight years later (Fujii et al., 2008), when an increase in the $\mathrm{p}$ values from 0.039 to 0.041 , respectively, was revealed. 
in addition, increases in various pollutants, including heavy metals, can also be expected. Metals such as $\mathrm{Zn}$ or Cd already account for mortality among macroalgae (Bouzon et al., 2011); however, these effects are compounded by the impact of climate change, making the situation even more worrisome, as Russell et al. (2009) have warned.

As previously noted, the variation of a single parameter can result in a cascade effect that changes a number of biological and ecological aspects of organisms and their environment, thus complicating the forecasting of future scenarios. This complexity is greater when other impacts of anthropogenic origin, such as those related to fishing or even pollution, are included in the discussion. Because of the complexity of causal factors and the lack of historical data on macroalgae diversity along the Brazilian coast, discussions or correlations of this scenario with global
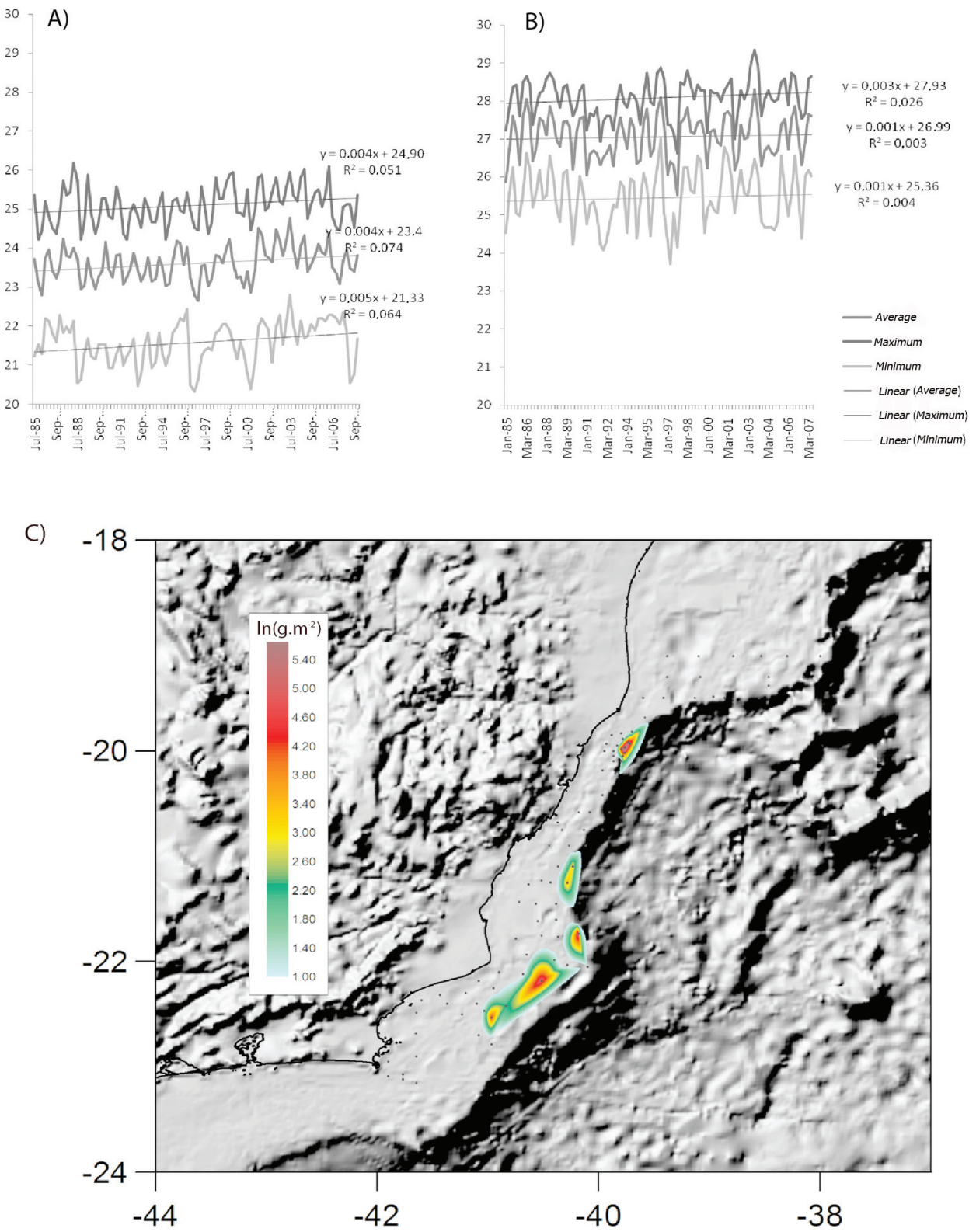

Figure 2. Sea surface temperature between 1985 and 2007 and biomass in 1988 (ln) of Laminaria abyssalis (Quége, 1988) in the southeastern Brazil subtidal coastal area (depth from 40 and $120 \mathrm{~m}$ ). a) Winter temperatures showing warming tendencies $\left(\mathrm{R}^{2}\right.$ and ANOSIN; $p=0.039)$; b) Summer temperatures with no significant trends; c) Distribution and biomass of $L$. abyssalis according to Quége (1988). 
Table 1. Spatial variation of biomass and richness at sites considered to be pristine-like (PLE) and Urbanized (URB) environments, highlighting the loss of diversity and, consequently, of biotechnological potential.

\begin{tabular}{lccccc}
\hline \multirow{2}{*}{ Sites } & \multicolumn{2}{c}{ Abundance $\left(\mathrm{g} / \mathrm{m}^{2}\right)$} & \multicolumn{2}{c}{ Richness } & \multirow{2}{*}{ Reference } \\
\cline { 2 - 5 } & PLE & UBE & PLE & UBE & Széchy et al., 2005 \\
\cline { 2 - 5 } Todos os Santos Bay, BA & $300^{*}$ & $30^{*}$ & 37 & 20 & Amado-Filho et al., 2003 \\
Sepetiba Bay, RJ & $500^{*}$ & $200^{*}$ & $40^{*}$ & 15 & Bouzon, 2005 \\
Santa Catarina North Bay, SC & $350^{*}$ & $50^{*}$ & 19.2 & 8 & Bouzon, 2005 \\
Santa Catarina South Bay, SC & $500^{*}$ & $70^{*}$ & 23.7 & 05 & \\
\hline
\end{tabular}

*values estimated from the analysis of graphs.

Table 2. Biomass and richness at distinct times at several different sites, highlighting the loss of diversity and, consequently, of biotechnological potential.

\begin{tabular}{|c|c|c|c|c|c|}
\hline \multirow{2}{*}{ Temporal variation in urban sites } & \multicolumn{2}{|c|}{ Abundance $\left(\mathrm{g} / \mathrm{m}^{2}\right)$} & \multicolumn{2}{|c|}{ Richness } & \multirow{2}{*}{ Reference } \\
\hline & Before & After & Before & After & \\
\hline Boa Viagem Beach, RJ & $*$ & $*$ & 62 & 45 & Taouil \& Yoneshigue-Valentin, $2002^{1}$ \\
\hline Sepetiba Bay, RJ & 490.9 & 199.57 & 13 & 5.06 & Reis, $2009^{2}$ \\
\hline Santos Bay, SP & * & * & 100 & 91 & Oliveira \& Qi, 2003³ \\
\hline Imbituba, SC & * & $*$ & 89 & 62 & Faveri et al., $2010^{4}$ \\
\hline
\end{tabular}

climate change or local stresses are compromised. Studies such as those of Taouil \& Yoneshigue-Valentin (2002) in Niterói, located on the Brazilian southeastern coast, point to the disappearance of groups such as representatives of the order Dictyotales, known to produce important biotechnological substances. This phenomenon was also observed by Oliveira \& Qi (2003) for Santos Bay on the southeastern Brazilian coast, by Bouzon et al. (2006) for Florianópolis and by Faveri et al. (2010) for Imbituba, both on the southern Brazilian coast. These last authors attributed the observed changes to global warming, as well as the overall impact of urbanization in recent decades. In addition to the decrease in the number of species (Table 1), the impacts of the synergistic effects of climate change and local stress factors result in losses in the abundance of macroalgae (Table 1 and 2), further compromising their biotechnological potential. From the initial stages of the isolation of chemical substances until the later stages of assessment of their activity, a reasonable amount of biomass is necessary. The differences observed in urban areas compared to pristine areas (Table 1), as well as the evolution of these communities in urban environments (Table 2), reinforce the concern that we are losing biotechnological potential.

Thus, it is clear that these changes, as observed in Brazil and, indeed, worldwide, have led to a loss of diversity and the resulting exclusion of species with high biotechnological potential. Solutions should be sought to mitigate this loss, to seek sustainable initiatives for the occupation of coastal areas, and to invest in sanitation and sewage treatment, especially in underdeveloped and developing countries

These initiatives should be accompanied by a selection process and the creation of new environmental protection areas in coastal regions around the world. This is especially true in Brazil since the areas currently safeguarded by conservation units are well below the number and extent required to adequately protect an important portion of our biodiversity (Amaral \& Jablonski, 2005), which clearly holds biotechnological importance but, up to now, has been poorly studied.

To ensure continuity of these initiatives, it is essential to create and maintain long-term data surveys, as well as to train professionals with interdisciplinary skills. Therefore we encourage the establishment and maintenance of research networks focusing on different aspects of issues related to climate change and its effects on biological diversity. With the implementation of such measures, Brazil, or any other maritime country in the world, can hope to conserve and exploit the biodiversity of its marine life sustainably, even considering the potentially different consequences of climate change.

\section{Acknowledgment}

The authors thank INCT-MC, Rede Clima Subnet Coastal Zones, CNPq and CAPES.

\section{References}

Amaral ACZ, Jablonski S 2005. Conservação da biodiversidade marinha e costeira no Brasil. Megadiversidade 1: 43-51.

Amado-Filho GM, Barreto MBB, Marins BV, Felix C, Reis 
RP 2003. Estrutura das comunidades fitobentônicas do infralitoral da Baía de Sepetiba, RJ, Brasil. Rev Bras Bot 26: 329-342.

Bouzon JL, Salles JP, Bouzon Z, Horta PA 2006. Aspectos florísticos e fitogeográficos das macroalgas marinhas das baías da Ilha de Santa Catarina, SC, Brasil. Insula 35: 69-84.

Bouzon ZL, Ferreira EC, Santos R, Horta PA, Maraschin M, Schmidt EC 2011. Influences of cadmium on fine structure and metabolism of Hypnea musciformis (Rhodophyta, Gigartinales) cultivated in vitro. Protoplasma 248: doi 10.1007/s00709-011-0301-6.

Bouzon JL 2005. Composição e estrutura espacial da comunidade macrofitobêntica de fundos consolidados das Baías da Ilha de Santa Catarina (SC): subsidios para a avaliação do impacto da urbanização. Florianópolis, 69p. Dissertação de Mestrado, Universidade Federal de Santa Catarina.

Cassano V, De-Pauloa JC, Fujii MT, da Gama BAP, Teixeira VL 2008. Sesquiterpenes from the introduced red seaweed Laurencia caduciramulosa (Rhodomelaceae, Ceramiales). Biochem Syst Ecol 36: 223-226.

Dillon ME, Wang G, Huey RB 2010. Global metabolic impacts of recent climate warming. Nature 467: 704-707.

Domingos TFS, Vallim MA, Carvalho C, Sanchez EF, Teixeira VL; Fuly AL 2011. Anti-snake venom effect of secodolastane diterpenes isolated from Brazilian marine brown alga Canistrocarpus cervicornis against Lachesis muta venom. Rev Bras Farmacogn 21: 234238.

Emanuel K 2007. Environmental factors affecting tropical cyclone power dissipation. J Climate 20: 5497-5509.

Faveri C, Farias JN, Scherner F, Oliveira EC, Horta PA 2010. Temporal changes in the seaweed flora in Southern Brazil and its potential causes. PanamJAS 5: 350357.

Fujii MT, Barata D, Chiracava S, Guimarães SMPB 2008. Cenário brasileiro da diversidade de algas marinhas bentônicas e sua contribuição para a política de conservação dos recursos naturais e do meio ambiente. In: 59 Congresso Nacional de Botânica Natal. Atualidades, Desafios e Perspectivas da Botânica no Brasil. Natal: Imagem Gráfica e Editora Ltda, p. 375 377.

Garrido V, Teixeira G, Teixeira VL, Ocampo P, Ferreira WJ, Cavalcanti DN, Campos SM, Pedruzzi MMB, Olaya P, Santos CCC, Giongo VA, Paixao ICNP 2011. Evaluation of the acute toxicity of dolabelladienotriol, a potential antiviral from the brown alga Dictyota pfaffii, in BALB/c mice. Rev Bras Farmacogn 21: 209-215.

Horta PA, Amancio E, Coimbra CS, Oliveira EC 2001. Considerações sobre a distribuição e origem da flora de macroalgas marinhas brasileiras. Hoehnea 28: 243-26.
Horta PA, Oliveira EC 2000. Morphology and reproduction of Anotrichium yagii (Ceramiales, Rhodophyta) a new invader seaweed in the American Atlantic? Phycologia 39: 390-394.

IPCC 2007. The physical science basis. Contribution of Working Group I to the Fourth Assessment Report of the Intergovernmental Panel on Climate Change, Vol. 1. Intergovernmental panel on climate change, Geneva, Switzerland.

Lhullier C, Falkenberg M, Ioannou E, Quesada A, Papazafiri P, Horta PA, Schenkel EP, Vagias C, Roussis V 2010. Cytotoxic halogenated metabolites from the Brazilian red alga. J Nat Prod 73: 27-32.

Machado FLS, Pacienza-Lima W, Rossi-Bergmann B, Gestinari LMS, Fujii MT, De-Pauloa JC, Costa SS, Lopes NP, Kaiser CR, Soares AR 2011. Antileishmanial sesquiterpenes from the Brazilian red alga Laurencia dendroidea. Planta Med 77: 733-735.

Marinho-Soriano E, Pinto E, Yokoya NS, Copelicolo P, Teixeira VL; Yoneshigue-Valentin Y 2011. Frontiers on algae bioactive compounds (Editorial). Rev Bras Farmacogn 21: 0-0..

Marques M, Costa MF, Mayorga MIO, Pinheiro PRC 2004. Water environments: anthropogenic pressures and ecosystem changes in the atlantic drainage basins of Brazil. Ambio 33: 68-77.

Marengo JA, Camargo CC 2007. Surface air temperature trends in Southern Brazil for 1960-2002. Int J Climatol 28: 893-904.

Moura LA, Bianco EM, Pereira RC, Teixeira VL, Fuly AL 2011. Anticoagulation and antiplatelet effects of a dolastane diterpene isolated from the marine brown alga Canistrocarpus cervicornis. J Throm Thrombolysis 31: 235-240.

Oliveira EC, Qi Y 2003. Decadal changes in a polluted bay as seen from its seaweed flora: the case of Santos Bay in Brazil. Ambio 32: 403-405.

Quége N 1988. Laminaria (Phaeophyta) no Brasil, Uma perspectiva econômica. São Paulo, 230p. Dissertação de mestrado, Depto. de Botânica, Universidade de São Paulo.

Reis RP 2009. Caracterização da assembléia fitobentônica da praia do Kutuca, ilha da Marambaia, baía de Sepetiba, RJ, Brasil. Acta Bot Bras 23: 297-304.

Rodrigues MA, Santos CP, Yoneshigue-Valentin Y, Strbac D, Hall DO 2000. Photosynthetic light-response curves and photoinhibition of the deep-water laminaria abyssalis and the intertidal Laminaria digitata (Pheophyceae). J Phycol 36: 97-106.

Romanos MT, Andrada-Serpa MJ, dos S, Ribeiro A, Yoneshigue-Valentin Y, Costa SS, Wigg MD 2002b. Inhibitory effect of extracts of Brazilian marine algae on human T-cell lymphotropic virus type 1 (HTLV-1)induced syncytium formation in vitro. Cancer Invest 20: 46-54. 
Romanos MT, Andrada-Serpa MJ, Mourão PA, YoneshigueValentin Y, Costa SS, Pereira MS, Miranda MM, Gonçalves JL, Wigg MD 2002a. A sulphated fucan from the Laminaria abyssalis inhibits the human $\mathrm{T}$ cell lymphotropic virus type 1-induced syncytium formation in HeLa cells. Antivir Chem Chemother 13: 219-221.

Russell BD, Thompson JAI, Falkenberg LJ, Connell SD 2009. Synergistic effects of climate change and local stressors: $\mathrm{CO}_{2}$ and nutrient-driven change in subtidal rocky habitats. Glob Change Biol 15: 2153-2162.

Széchy MTM, Amado Filho GM, Cassano V, Paula JC, BarrosBarreto MB, Reis RP, Marins-Rosa BV, Moreira FM 2005. Levantamento florístico das macroalgas da baía de Sepetiba e adjacências, RJ: ponto de partida para o Programa GloBallast no Brasil. Acta Bot Bras 19: 587-596.

Steffen W, Persson A, Deutsch L, Zalasiewicz J, Williams M, Richardson K, Crumley C, Crutzen P, Folke C, Gordon L, Molina M, Ramanathan V, Rockströo“m J, Scheffer M, Schellnhuber HJ, Svedin U 2011. The Anthropocene: From Global Change to Planetary Stewardship. Ambio 40: 739-761.
Sudatti DB, Fujii MT, Rodrigues SV, Turra A, Pereira RC 2011. Effects of abiotic factors on growth and chemical defenses in cultivated clones of Laurencia dendroidea J. Agardh (Ceramiales, Rhodophyta). Mar Biol 158: 1439-1446.

Taouil A, Yoneshigue-Valentin Y 2002. Alterações na composição florística das algas da Praia de Boa Viagem (Niterói, RJ). Rev Bras Bot 25: 405-412.

Yoneshigue-Valentin Y 1990. The life cycle of Laminaria abyssalis Joly et Oliveira Filho (Laminariaceae, Laminariales, Phaeophyta) in culture. Hydrobiologia 204/5: 461-466.

Zagoni M 2010. A question of trust. Nature 466: 7-7.

\section{*Correspondence}

Paulo Antunes Horta

Universidade Federal de Santa Catarina,

Campus Universitário Trindade, 88010-970 FlorianópolisSC, Brazil

pahorta@ccb.ufsc.br

Tel. +554837218544

Fax: +55 4837218545 